This item was submitted to Loughborough's Research Repository by the author.

Items in Figshare are protected by copyright, with all rights reserved, unless otherwise indicated.

\title{
Global reversal, regional revival?
}

PLEASE CITE THE PUBLISHED VERSION

http://dx.doi.org/10.1080/00343404.2016.1255720

\section{PUBLISHER}

Taylor \& Francis @ Regional Studies Association

\section{VERSION}

AM (Accepted Manuscript)

\section{PUBLISHER STATEMENT}

This work is made available according to the conditions of the Creative Commons Attribution-NonCommercialNoDerivatives 4.0 International (CC BY-NC-ND 4.0) licence. Full details of this licence are available at: https://creativecommons.org/licenses/by-nc-nd/4.0/

\section{LICENCE}

CC BY-NC-ND 4.0

\section{REPOSITORY RECORD}

Turok, Ivan, David Bailey, Jennifer Clark, Jun Du, Ugo Fratesi, Michael Fritsch, John Harrison, et al.. 2019.

"Global Reversal, Regional Revival?". figshare. https://hdl.handle.net/2134/26104. 


\section{Global reversal, regional revival?}

\section{Final author version}

This article is now published. To cite please use the following:

Ivan Turok, David Bailey, Jennifer Clark, Jun Du, Ugo Fratesi, Michael Fritsch, John Harrison, Tom Kemeny, Dieter Kogler, Arnoud Lagendijk, Tomasz Mickiewicz, Ernest Miguelez, Stefano Usai, Fiona Wishlade. (2017) Global reversal, regional revival?. Regional Studies 51:1, pp 1-8 doi.org/10.1080/00343404.2016.1255720

\section{INTRODUCTION}

Regional Studies celebrates its 50th anniversary with this special issue. This introductory article reflects back on developments since the journal was started and offers signposts for urban and regional research looking ahead. It outlines the changing global context for regional studies and identifies some of the ways in which the need for regional research is enhanced by the extraordinary challenges currently confronting the world. It also introduces important themes from the recent history of the journal that are likely to feature in future. This is obviously a highly selective exercise, given the considerable breadth and depth of regional research over the years.

Regional Studies was launched into a very different environment where regions and nations were more self-contained and there was little dispute that space, place and proximity really mattered. There were no personal computers and no containerized transport, let alone the internet and digital devices enabling instantaneous sharing of information around the world. In the global North this was an optimistic era of full employment, rising prosperity, and diminishing social and spatial inequalities. It was also a period of relative political stability and ignorance of global warming, although the Cold War and nuclear threats loomed large, and there was growing unrest in many countries in the global South. In the North, capital and labour markets were closely regulated, and social protection systems were extensive. Regional studies was a new academic field, with very few journals focused on the development of sub-national territories.

Circumstances have changed radically since then. 'Globalization' sums up many influential trends, typified by the interconnection of regions and nations through cross-border flows of trade, capital, labour, technology and information. The increasing openness of territorial boundaries and the integration of world markets have rewarded highly skilled groups, wellpositioned city-regions and selected emerging economies, illustrated by the burgeoning of manufacturing in the Asian Tigers and China. However, freer trade and financial deregulation have also been accompanied by economic volatility and financial instability. Deindustrialization, privatization and welfare reductions in many advanced economies have enlarged social and spatial inequalities and left low- and middle-income groups worse off than before. 
Falling transport costs, heightened human mobility and new communications technologies have prompted many economists to predict the death of distance and the demise of cities and regions. Geographers have recognized that conditions have changed by proposing a more permeable, fluid concept of the region, and focusing more on the shifting flows, movements and relationships between regions. Intensified competition for trade, talent and multinational investment has amplified regional disparities by raising the stakes for winning, and leaving less-favoured people and places further behind, bearing the costs of adjustment in lower wages and lost jobs, and fuelling a sense of injustice (Ballas, Dorling, \& Hennig, 2017, in this issue). Regional research has become a broader, multidimensional endeavour, combining knowledge and insights from a range of disciplines beyond economic geography.

Since the financial crisis of 2008 and the protracted period of sluggish and unequal growth, the impetus to hyper-globalization has stalled. The frailty of most advanced economies, financial austerity and a shift in the balance of global power towards emerging economies in the East have provoked anxiety and frustration in the West (Dunford \& Liu , 2016, in this issue). People have felt buffeted by forces beyond their control and questioned the benefits of intertwined world markets. Resentment towards new waves of immigration and international institutions has risen, epitomized by Britain's vote to exit Europe, despite the broad economic consensus that this is not in the national interest. Global trade and capital flows have been pushed into reverse by rising protectionism and the dismantling of freetrade agreements. Tough patriotic sentiments are partly responsible for large financial penalties imposed on foreign multinationals such as Apple, Google, Deutsche Bank, Volkswagen and BP. At the very time when international cooperation is required to mitigate the risks of climate change, illicit financial flows, escalating refugee crises and mounting threats to security and peace, popular opinion seems to favour going it alone. Enlightened thinking also risks being crowded out by uncompromising - even chauvinistic - reactions to unfolding events.

The implications for cities and regions of the fracturing of the international order are highly uncertain. Resurgent popular nationalism would have profound consequences for all territories by inhibiting foreign direct investment (FDI), external trade and access to scarce skills, and forcing more reliance on local capabilities and domestic production. Some argue that a reversal of globalization would dampen economic progress and suppress opportunities for the world's poorest places and populations. Alternatively, patriotic impulses that challenge ossified structures and global cartels could provoke a resurgence of regional enterprise and organic growth. Well-conceived policy reforms that disrupt business inertia could engender another Schumpeterian wave of innovation and creativity based on smaller-scale production. Dynamic regional multipliers might be spurred by efforts to localize resource flows so as to secure the supply of food and scarce materials, to cut energy consumption and to regenerate degraded ecosystems. Enhanced democratic constraints on business short-termism may also curb financial speculation and encourage longer-term investment in the real economy.

Furthermore, international disengagement might serve to bolster local and regional identities and renew a sense of place and belonging. This could elevate the obligations on 
civic leaders and rebuild confidence in the role of city and regional institutions. Against this, heightened perceptions of fear and insecurity could foster a 'new tribalism' through separatist movements, ethnic tensions, insurgent splinter groups and other inward-looking forces that escalate conflict and pull countries and regions apart. Much depends on whether democratic institutions are capable of responding to the genuine concerns of citizens and can meld different interests and values together in pursuit of shared agendas and collective solutions. Meanwhile, if the Paris climate deal leads to restrictions on fossil fuel extraction in favour of clean energy, this could make many regions reliant on oil, gas and coal reserves vulnerable to stranded assets and obsolete power generation systems. The case for regional studies is accentuated rather than diminished in all these scenarios. Systematic analyses of how different territories are adapting to the unravelling of globalization and introducing more holistic and resilient strategies to cope with the turbulence are urgently needed. Over the last three decades, global integration has favoured selected metropolitan regions as strategic nodes in international networks of financial, trade and information flows. Dense agglomerations have functioned as knowledge hubs and magnets of entrepreneurial dynamism, thereby spurring wider productivity improvements and prosperity (Florida, Adler \& Mellander, 2016, in this issue). Major city-regions with far-sighted leadership challenge nations as economic entities and demand enhanced powers and resources to lead the recovery and promote more robust growth. The new conventional wisdom suggests that compact and connected cities drive competitiveness, cohesion and sustainable development (Buck, Gordon, Harding, \& Turok, 2005). Yet this is far from straightforward or inevitable. Addressing urban infrastructure deficits, integrating migrant populations through affordable housing, and mitigating spiralling carbon emissions presents a formidable policy agenda for which most city governments are ill-prepared. Traditional bureaucracies also lack the agility and capacity for cooperation and learning required to meet complex contemporary challenges. Taking a fashionable example, driverless cars could reduce congestion, improve efficiency, transform the urban environment and save many lives. Yet introducing this technology requires many subtle policy changes which depend on city and national authorities working hand in hand with car-makers and other interests to agree new safety standards, liability issues and more responsive regulatory procedures.

Meanwhile, the rural-urban transition in the global South has emerged as an exceptional opportunity to transform the structure of economies based on agriculture and mineral resources, and to raise living standards across the board. Yet, the scale and rate of urbanization in Africa and Asia are daunting challenges to avoid dysfunction and disaster if population growth in sprawling mega-cities continues to outstrip industrialization and local government's capacity to manage the process through coordinated investments in land, infrastructure and housing (Turok, 2016). Concentrated populations can spur economic progress and political reform through the pressure for change and necessity-driven innovation (Glaeser \& Steinberg, 2017, in this issue). Yet overcrowded human settlements can also foment social conflict over competition for scarce resources and vulnerability to flooding, fire, disease and other environmental hazards. There is a sizeable research agenda to understand the physical and institutional conditions required to ensure that urbanization 
fosters broad-based development, while avoiding the degradation and exploitation experienced historically in the North.

These socio-economic, spatial and environmental trajectories and transitions provide fertile terrain for theoretical development and empirical research. The character and determinants of lasting prosperity are bound to vary in different contexts, but not enough is known about how and why. Theories of economic development have variously and separately emphasized the importance of resource endowments, physical infrastructure, finance and productive investment, skills and human capital, advanced knowledge and innovation, and the quality of public institutions and leadership. The synergies between them are clearer and more concrete at the city and regional levels than at the national level. The respective roles of the state and market are also likely to vary in different circumstances, but in ways that are poorly understood and articulated at present. Neither exists in a vacuum or in an abstract 'national' space. A more balanced and interactive relationship between government, private sector and civil society may be important to come to terms with the wicked problems outlined above.

What follows is a selection of key themes that have featured prominently in Regional Studies in recent years and that are likely to be influential in future. The editors' choice of topics is reflected in the papers selected for publication in this special issue.

\section{THE CONCEPT AND POLITICS OF THE REGION}

Despite sustained interrogation, the region remains an elusive concept with multiple meanings (Keating, 2016, in this issue). The debates over regions surround what and where they are; why and how they are there; and what they do and for whom they do it. These questions occupy academics and policy-makers like never before, in places and settings that demonstrate the growing significance of the region in many different realms (Paasi \& Metzger, 2016, in this issue). Basic concerns relating to how we interrogate regions and regional development remain central. Emergent thinking challenges any notion that there is a singular logic for regions. It is vital for researchers to explore the raison d'être and diverse forms of such places and social constructs (Agnew, 2013).

This is apparent in the twin drivers of territorial change - economic and political - which remain at the heart of advancing regional studies. Over the last decade there has been significant effort to go beyond the classic territorial-relational divide, such that regions are seen as the outcome of both external relationships and internal territorial processes. The geographical extension and internationalization of regional studies are also noteworthy in bringing forward new knowledge and challenging established ideas. Accounts of Southern urbanism have done much to enliven recent debates (e.g., Lawhon, Silver, Ernstson, \& Pierce, 2016; Roy, 2011); their new insights provoking researchers to reflect on how theories and concepts are shaped by geographical and political contexts (Peck, 2015). Paasi and Metzger (2016, in this issue) take up the challenge of conceptualizing the region. All new approaches tend to criticize previous ideas for reducing or reifying the region in some way. Drawing on a Latourian reading of actor-network theory (ANT), they ask searching 
questions about who or what is ascribing regionality to an entity, how and why they are doing this, and what this concept actually does, or means, as a result? The implications are threefold: (1) it is a timely reminder that it is never the spatial form that acts, but rather social actors embedded in particular spatial forms who act; (2) emphasizing the role of agency and interests in regionalization processes reinforces the need for accounts grounded in everyday social practices; and (3) the regional studies community should enact and perform regional studies in such a way that its own research practices are open to scrutiny.

Keating (2016, in this issue) deepens the idea of construction in how regions are conceptualized and operationalized. Six frames are presented as drivers of political and institutional change, and keys for analysing the main dimensions of regionalism. Each frame is underpinned by different logics which, because they point in different directions, provide divergent outlooks on how regionalism should be practised. Often at work in the same places, this paper acts as a timely intervention demonstrating how conflicts are worked out in the realm of politics, which remains an important focus for regional studies.

The rapid pace of internationalization means that local and regional development is now recognized as a global concern. Pike, Rodríguez-Pose, \& Tomaney (2016, in this issue) trace the evolution of thinking about territorial development over the last 50 years. They note that practices vary greatly, despite globalizing trends. More importantly, the experience of regionalism and the impacts of development are increasingly uneven too. Researchers retain an important role in improving the evidence base to inform more progressive, spatially balanced outcomes for localities and regions.

\section{ENTREPRENEURSHIP IN A REGIONAL CONTEXT}

Regional Studies has been a vital forum for debates about regional entrepreneurship, with special issues published in 1984, 1994, 2004 and 2014 (Fritsch \& Storey, 2014). Efforts to understand the determinants of regional entrepreneurship have benefited from positioning the spatial context alongside the personality traits of business founders, their social relations and the degree of acceptance of self-employment within their regions (Kibler, Kautonen, \& Fink, 2014; Westlund, Larsson, \& Olsson, 2014). Important research has also been undertaken on entrepreneurship as a route out of poverty (Frankish, Roberts, Coad, \& Storey, 2014), and the role of new business formation in stimulating regional competition, productivity and innovation (e.g., Berlemann \& Jahn, 2015; Brixy, 2014).

An unresolved issue that warrants further research is to distinguish between different types of new business, and to identify innovative and knowledge-intensive start-ups that play a distinctive role in regional growth. Florida et al. (2016, in this issue) propose this line of investigation by bringing together city context, radical innovation and the formation of impactful new firms. They situate Jane Jacobs alongside Joseph Schumpeter at origins of entrepreneurship theory. A systemic analysis of the performance of different types of startups could usefully incorporate a region's historical development, industrial structure, ownership structure and availability of resources (Szerb, Acs, Autio, Ortega-Argilés, \& Komlósi, 2013). Multilevel analyses linking individual attributes - family background, 
education, employment history, personality etc. - to their regional context would be invaluable for improved academic understanding and policy purposes.

Another promising avenue for research involves combining entrepreneurship with emerging analysis of the quality of institutions (Rodríguez-Pose \& Garcilazo, 2015). Multiple attributes need to be incorporated, including formal institutions, social capital, culture and traditions. Since formal systems such as tax laws and labour market regulations tend to be uniform across each country, the informal institutions are particularly relevant. Recent analyses have revealed a surprising persistence of entrepreneurship levels over long periods (Fritsch \& Wyrwich, 2014). This seems to be conducive to resilience against external shocks and to promote regional growth (Glaeser, Kerr, \& Kerr, 2015). The regional culture of entrepreneurship seems important, but poorly understood. Sizeable variations also exist in countries with dispersed spatial structures and federal political systems. This is even more pronounced in emerging economies, where regional entrepreneurship research remains undeveloped.

\section{THE GEOGRAPHY OF INNOVATION}

Entrepreneurship is often associated with innovation, and recent literature on the sources of economic growth leaves little doubt that this is a key driver of national and regional prosperity. Regional Studies has published many papers on regional innovation activity and technological change. Policies to stimulate development often assume that highly ranked regions offer templates that can be applied elsewhere. There are many fallacies in such an approach, including disregarding the unique conditions in each region which generate distinctive capacities and patterns of specialization over time. A best-practice approach also neglects how actors involved in creating new ideas are embedded in complex regional and international networks of production and value creation. These are not easily reproduced or transferred elsewhere.

Theories of economic development would benefit from shifting away from a top-down perspective towards more of a bottom-up approach where knowledge production, creativity and entrepreneurship are the starting points and prosperity is the outcome. Recent research in Evolutionary Economic Geography offers fresh insights in this regard by examining how knowledge production is translated into regional economic fortunes (Kogler, 2015). It starts with regional scientific and technological competencies that develop into place-specific development trajectories (Boschma \& Martin, 2010; Kogler, Rigby, \& Tucker, 2013). The emphasis is on understanding the factors leading to knowledge production and then analysing the dynamics leading to the introduction and diffusion of novel products and processes.

Many studies in the field of regional innovation currently focus on large cities, especially those considered to be exemplars of strong performance. Although cities may be 'innovation machines' (Florida et al., 2016, in this issue) that drive the development of nations, other locations may also generate new knowledge with the potential to initiate technological change (Glückler, 2014). Moreover, some cities are more innovative than 
others, and this varies between countries and continents. It may be that development theories need more careful adaptation to different contexts (Roy, 2011; Scott \& Storper, 2015). An important avenue for future research pertains to the role of networks in fostering innovation. The contribution of public entities to initiating and supporting innovation is also frequently underestimated.

Universities have always been important sites for knowledge production, traditionally focused on basic research and educating graduates. Contemporary universities are also expected to engage in entrepreneurial activities, but can get caught between supply-push and demand-pull approaches to innovation. Spin-off and start-up activities are popular areas of research, yet lacking an understanding of the transfer mechanisms between basic science and applied research (Feldman \& Kogler, 2010). The role of entrepreneurs is particularly important - the interplay between individuals, institutions and local knowledge potential offers fresh insights into innovation processes at large.

\section{GLOBAL NETWORKS}

Debates about the relative importance of economic relationships within and between regions date back to the seminal contribution of Alfred Marshall. Recent research has emphasized the need to locate regions in their wider context and to recognize forms of proximity other than geographical. Linkages and networks that channel knowledge across space through cognitive, organizational and social dimensions play crucial roles as complements to, or substitutes for, physical proximity. The extent to which economic trajectories are shaped by local interactions ('buzz') or global connections ('pipelines') will vary between different types of locality, activity and actors involved.

Multinationals may be uniquely placed to influence both local and global scenarios. Their relationship to regions has been mostly studied through the lens of global production networks (Coe \& Yeung, 2015), where global value chains and connectivity chains are understood in relation to the loci of value creation. This is a crucial issue with the extension of FDI from manufacturing to services, which now represent the majority of total flows. Emerging economies also play an increasingly important role in FDI. They tend to concentrate on neighbouring countries, which gives rise to complex spatial structures. South-South linkages are also growing, exemplified by China's expanding investments in agriculture, mining and industrial production in Africa.

Regional development is shaped by increasingly complex flows of different forms, strengths and directions (Crescenzi \& lammarino, 2017, in this issue). The connectivity networks of regions allow economic agents to gain access to knowledge diffused from elsewhere, and thereby capture some of the benefits of knowledge creation processes, which tend to be more highly concentrated. Such insights represent advances on the traditional FDI literature, which has tended to focus on the factors that make regions attractive to external investment.

The role of finance in regional development has been neglected compared with manufacturing and services. Research has focused on locational decisions without interrogating the peculiarities of this sector, such as the uncertainty and imperfect 
information characterizing financial procedures. Understanding the geography of finance requires knowledge of the internal mechanisms of such organizations, as well as the traditional tools of regional analysis. Knight and Wojcik (2016, in this issue) extend the concept of financial information beyond the usual transactions between firms to include more strategic information in relation to resource allocation and product and process innovation. This provides a finer-grained and more dynamic perspective on the activities of financial institutions. Their decisions about whether to invest or disinvest, and where to locate their headquarters and other operations, have major impacts at the regional scale and are based on a combination of the external environment and internal strategies.

\section{MIGRATION AND MOBILITY}

Record inflows of asylum-seekers and economic migrants to Europe and elsewhere in recent years have pushed migration to the forefront of many political agendas. The sensitivity of large-scale migration makes it imperative to strengthen the evidence base in the face of prejudice and misinformation. A better understanding might assist policy- makers to move beyond a reactive approach and towards strategies that promote integration. Key themes for research include the root causes, mechanisms and consequences of migration for sending and receiving regions, the diverse social composition of migration flows and the role of temporary migration. Regional Studies has a strong track record of publishing work on regional migration, including the implications for territorial development. Lack of reliable, comparable migration data has been a perennial constraint.

The migration of highly skilled and qualified people, such as graduates, scientists, engineers, senior managers and entrepreneurs, has been of particular interest in recent years because of their disproportionate economic impact (Kubis \& Schneider, 2015). Research has explored the determinants of their geographical mobility and the consequences for the flow of expertise and ideas between regions (lammarino \& Marinelli, 2015; Krabel \& Flöther, 2014; Nifo \& Vecchione, 2014). A longstanding question has been whether human capital is attracted more by the quality of local amenities or the availability of jobs. Another major debate has concerned the impact of migration on the regional economy, including whether incomers displace local workers and depress wages, or bring benefits in the form of knowhow, new technology and investment (Faggian, Rajbhandari, \& Dotzel, 2017, in this issue).

Despite the improved understanding of human capital mobility, many issues require further research. Outstanding questions surround the principal sources of attraction of those who generate knowledge and ideas, and the processes by which they migrate. Temporary migration is a neglected topic, enabling the circulation of information and expertise, and the building of relationships between regions. It can take many forms, including research visits by scientists to other laboratories, exchange programmes by professionals and academics, expatriate workers sent to foreign subsidiaries, and short-term migration to acquire skills and work experience. More research is also needed on the consequences of mobility for the regions left behind, including the long-term effects of a brain drain and loss of economic dynamism. The tendency to devolve powers over education and training policy to regional and local governments could discourage investment in people if they simply migrate elsewhere afterwards. Yet skilled migration can also benefit the sending region through the 
return flows of ideas, skills and techniques, and the potential to establish economic linkages across regions (Faggian et al., 2017, in this issue). The shifting trajectories of migration movements and the socio-economic and political barriers to refugee integration are other themes for investigation.

\section{INFRASTRUCTURE AND REGIONAL DEVELOPMENT}

Infrastructure has long been a focus of policies to bolster regional development. These investments are often highly visible and politically attractive, but because of their largescale character, they pose risks of major cost overruns, environmental damage and overstated developmental effects. Public procurement provides an economic stimulus generating many jobs and other spinoffs during their construction. The completed projects are intended to produce more efficient, liveable and safer cities and regions that encourage private investment, as long as the costs are not prohibitive and the infrastructure is maintained and renewed before it decays. Many of these schemes are transport related. Chen and Vickerman (2016, in this issue) focus on a comparison of high-speed rail (HSR) projects in China and the UK. They identify methodological challenges in evaluating such projects, highlighting how methods have evolved from simple cost-benefit analyses to more sophisticated efforts to distinguish different scales of economic impact (local, regional, national) and incorporate enhancements in economic performance achieved through efficiencies, accessibility and agglomeration.

Regional Studies has a particular interest in the spatial distribution of the beneficiaries of infrastructure investments. Chen and Vickerman demonstrate that HSR often makes core areas more accessible at the expense of peripheral regions, which remain passed over (or passed through) places. The development promised by advocates of HSR accrues to advanced regions with the capacity to absorb the accessibility advantages. More widespread benefits would require additional investments in connectivity to local networks and careful integration of HSR stations into local land-use plans to ensure coherent urban development. This echoes the message of urban planning that investment in subways, light rail, trams and bus rapid transport systems need to be aligned with other sectoral and spatial plans. It is apparent in the burgeoning interest in higher density, mixed-use transit-oriented development.

The role of infrastructure in regional development also covers information and communications technologies (ICTs). These are vital to regional competitiveness, including globally connected cities as well as peripheral regions. The role of the public sector is more ambiguous in ICT investments than in transport or utilities such as water and sanitation, where the state is often the only actor with the authority and resources to deliver the required facilities at scale. The 'smart cities' discourse merges ICT and urban infrastructure, and reflects the transition to thinking about accessibility and efficiency as a matter of mitigating the costs of movement of people and goods, including the environmental damage. The state performs a sophisticated and dynamic role as a regulator, funder and user of these schemes. Research can make an important contribution in establishing appropriate evaluation criteria, in analysing the consequences of smart city investments for 
urban productivity, liveability and sustainability, and in providing feedback to promote policy learning and improvement over time.

\section{THE TRANSITION TO A GREEN ECONOMY}

Environmental research and policy has mirrored the trajectory of Regional Studies in shifting from a local to a global orientation. It is no longer sufficient to analyse and manage the use of natural resources and consequential environmental degradation the local and regional scales. Globalization has been accompanied by a rapid increase in the extraction and consumption of fossil fuels, minerals, biomass, water, agricultural land, forests and biodiversity (Bringezu et al., 2016). The new sustainable development goals require all countries to measure progress towards more efficient and enduring use of these resources, which will in turn require ambitious efforts to drive more responsible behaviour by firms, industries, households and governments (Graute, 2016). Stronger global conventions and governance arrangements may be needed to monitor and regulate the production and consumption of natural resources in order to mitigate the harm for local communities, ecosystems, economies and the planet as a whole. Without this broader perspective, the environmental burdens could easily be displaced from wealthy regions onto weaker and poorer places.

The coincidence of looming environmental threats with the global economic slowdown and rising social inequality has prompted a search for broad-based and mutually beneficial policy responses. The green economy is one of the umbrella concepts (along with the circular economy or low-carbon economy) that could draw together diverse sectoral, economic and territorial interests around a shared agenda (Borel-Saladin \& Turok, 2013). It offers a positive vision of the future, in contrast to the apocalyptic perspective common in the environmental literature. It promises a targeted economic stimulus to launch the transition to a low-carbon, more equitable economy, and to spur longterm prosperity based on new technologies and improvements in resource efficiency. This recognizes that things can be done to reverse the destruction of ecosystems while simultaneously improving human wellbeing. The emphasis is on pursuing the combined benefits of interactions between the economy and the environment, rather than accepting trade-offs and compromises. A good example is the idea of shifting from the current system of production and consumption, which is based on a linear process from natural resource extraction to waste, towards a more circular economy encompassing repair, reassembly, refurbishment and recycling.

Gibbs and O'Neill (2016, in this issue) confirm the significance of the green economy for regional development, but with an important caveat. When environmental concerns are addressed, this often takes the form of 'greenwashing', i.e., thinly veiled versions of business as usual. Rather than launching a process of social and environmental transformation, the priorities of green economy initiatives may be much more limited in practice and remain locked into established techniques and paradigms. To induce genuine change, green economy schemes need to be grounded within a broader transition framework (Boschma, Coenen, Frenken, \& Truffer, 2017, in this issue). Cities and regions can play prominent roles by promoting innovative niches oriented to alternative forms of production and consumption. They may prompt important changes in the regime level of 
rules and institutions by experimenting with different regulations. This may alter the various relationships that enable and accelerate the transition. Local niches can thereby foster shifts in the paradigm and establish important milestones in progressing towards more resilient and sustainable futures (Boschma et al., 2017, in this issue). This seems some way off at present. Gibbs and O'Neill (2016, in this issue) provide telling examples of how radical initiatives concerned with slow food and de-growth can move beyond local niches and act as symbols of broader change. Yet, can such practices really have wider, paradigmatic consequences? Multiple local practices may be able to bind many different places together in a shared transition trend, thereby extending niches from the local to global level. However, moving beyond such niches to influence broader systems is extremely challenging. Deeper transitions may require political advocacy going beyond green initiatives and transitions research. Regional Studies may have a valuable role to play in exploring the interaction between economic, technological, institutional and political systems at different scales to yield novel insights which facilitate real progress in moving towards more sustainable and inclusive economies.

\section{CONCLUSIONS}

A 50th anniversary is a significant landmark in the development of any institution. This special issue is an opportunity to review how Regional Studies has developed over time and where it is heading. It deliberately sets out to reflect on what can and should be learnt from past urban and regional research, and to be agenda-setting by including ideas at the forefront of regional thinking. It outlines the changing global context of regional studies and some of the factors that are bound to influence the journal's development. A novel feature is the collaboration between many established academics and emerging scholars from across the world to share knowledge and incorporate different perspectives. Above all, the special issue calls for a greater awareness of the shifting international environment for regional studies and identifies some of the key strategic concerns facing regional development theory and policy.

\section{REFERENCES}

Agnew, J. A. (2013). Arguing with regions. Regional Studies, 47(1), 6-17. doi:10.1080/00343404.2012.676738

Ballas, D., Dorling, D., \& Hennig, B. (2017) Analysing the regional geography of poverty, austerity and inequality in Europe: A human cartographic perspective, Regional Studies. doi:10.1080/00343404.2016.1262019

Berlemann, M., \& Jahn, V. (2015). Regional importance of Mittelstand firms and innovation performance. Regional Studies, 49, 1819-1833.

Borel-Saladin, J., \& Turok, I. (2013). The Green economy: Incremental change or transformation? Environmental Policy and Governance, 23, 209-220. doi:10.1002/eet.1614

Boschma, R., Coenen, L., Frenken, K., \& Truffer, B. (2017). Towards a theory of regional diversification: combining insights from Evolutionary Economic Geography and Transition Studies. Regional Studies. doi:10.1080/00343404.2016.1258460 
Boschma, R. A., \& Martin, R. L. (Eds.). (2010). Handbook of evolutionary economic geography. Chichester: Edward Elgar.

Bringezu, S., Potocnik, J., Schandl, H., Lu, Y., Ramaswami, A., Swilling, M., \& Suh, S. (2016). Multi-scale governance of sustainable natural resource use - challenges and opportunities for monitoring and institutional development at national and global level. Sustainability, 8 , 778-803. doi:10.3390/su8080778

Brixy, U. (2014). The significance of entry and exit for regional productivity growth. Regional Studies, 48, 1051-1070. doi:10.1080/00343404.2014.895804

Buck, I., Gordon, I., Harding, A., \& Turok, I. (Eds.). (2005). Changing cities: Rethinking urban competitiveness, cohesion and governance. London: Palgrave.

Chen, C., \& Vickerman, R. (2016). Can transport infrastructure change regions' economic fortunes?: Some evidence from Europe and China. Regional Studies. doi:10.1080/00343404.

2016.1262017

Coe, N. M., \& Yeung, H. W. (2015). Global production networks: Theorizing economic development in an interconnected world.

http://doi.org/10.1093/acprof:oso/9780198703907.001.0001

Crescenzi, R., \& lammarino, S. (2017). Global investments and regional development trajectories: The missing links. Regional Studies. doi:10.1080/00343404.2016.1262016

Dunford, M., \& Liu, W. (2016). Uneven and combined development. Regional Studies. doi:10.1080/00343404.2016.1262946

Faggian, A., Rajbhandari, I., \& Dotzel, K. R. (2017). The interregional migration of human capital and its regional consequences: a review. Regional Studies.

doi:10.1080/00343404.2016.1263388

Feldman, M. P., \& Kogler, D. F. (2010). Stylized facts in the geography of innovation. In B. Hall, \& N. Rosenberg (Eds.), Handbook of the economics of innovation (pp. 381-410). Oxford: Elsevier.

Florida, R., Adler, P., \& Mellander, C. (2016). The city as innovation machine. Regional Studies. doi:10.1080/00343404.2016. 1255324

Frankish, J. S., Roberts, R. G., Coad, A., \& Storey, D. J. (2014). Is entrepreneurship a route out of deprivation? Regional Studies, 48, 1090-1107. doi:10.1080/00343404.2013.871384

Fritsch, M., \& Storey, D. J. (2014). Entrepreneurship in a regional context: Historical roots, recent developments and future challenges. Regional Studies, 48, 939-954.

doi:10.1080/00343404.2014.892574

Fritsch, M., \& Wyrwich, M. (2014). The long persistence of regional levels of entrepreneurship: Germany, 1925-2005. Regional Studies, 48, 955-973.

doi:10.1080/00343404.2013.816414 
Gibbs, D., \& O'Neill, K. (2016). Future green economies and regional development: A research agenda. Regional Studies. doi:10.1080/00343404.2016.1255719

Glaeser, E., \& Steinberg, B. (2017). Transforming cities: does urbanization promote democratic change?. Regional Studies. doi:10.1080/00343404.2016.1262020

Glaeser, E. L., Kerr, S. K., \& Kerr, W. K. (2015). Entrepreneurship and urban growth: An empirical assessment with historical mines. Review of Economics and Statistics, 97, 498-520. doi:10.1162/REST_a_00456

Glückler, J. (2014). How controversial innovation succeeds in the periphery? A network perspective of BASF Argentina. Journal of Economic Geography, 14(5), 903-927. doi:10.1093/jeg/lbu016

Graute, U. (2016). Local authorities acting globally for sustainable development. Regional Studies, 50(11), 1931-1942. doi:10.1080/00343404.2016.1161740

lammarino, S., \& Marinelli, E. (2015). Education-job (mis)match and interregional migration: Italian university graduates' transition to work. Regional Studies, 49, 866-882.

doi:10.1080/00343404.2014.965135

Keating, M. (2016). Contesting European regions. Regional Studies.

doi:10.1080/00343404.2016.1227777

Kibler, E., Kautonen, T., \& Fink, M. (2014). Regional social legitimacy of entrepreneurship: Implications for entrepreneurial intention and start-up behaviour. Regional Studies, 48, 995-1015. doi:10.1080/00343404.2013.851373

Knight, E., \& Wojcik, D. (2016). Geographical linkages in the financial services industry: a dialogue with organizational studies. Regional Studies.

doi:10.1080/00343404.2016.1254768

Kogler, D. F. (2015). Editorial: Evolutionary Economic Geography - Theoretical and empirical progress. Regional Studies, 49(5), 705-711. doi:10.1080/00343404.2015.1033178

Kogler, D. F., Rigby, D. L., \& Tucker, I. (2013). Mapping knowledge space and technological relatedness in U.S. cities. European Planning Studies, 21(9), 1374-1391.

doi:10.1080/09654313.2012.755832

Krabel, S., \&Flöther, C. (2014). Here today, gone tomorrow? Regional labour mobility of German university graduates. Regional Studies, 48, 1609-1627.

doi:10.1080/00343404.2012.739282

Kubis, A., \& Schneider, L. (2015). Regional migration, growth and convergence - A spatial dynamic panel model of Germany. Regional Studies, 0, 1-15.

Lawhon, M., Silver, J., Ernstson, H., \& Pierce, J. (2016). Unlearning (un)located ideas in the provincialization of urban theory. Regional Studies, 50(9), 1611-1622.

doi:10.1080/00343404.2016.1162288 
Nifo, A., \& Vecchione, G. (2014). Do institutions play a role in skilled migration? The case of Italy. Regional Studies, 48, 1628-1649. doi:10.1080/00343404.2013.835799

Paasi, A., \& Metzger, J. (2016). Foregrounding the region. Regional Studies. doi:10.1080/00343404.2016.1239818

Peck, J. (2015). Cities beyond compare? Regional Studies, 49(1), 160-182. doi:10.1080/00343404.2014.980801

Pike, A., Rodríguez-Pose, A., \& Tomaney, J. (2016). Shifting horizons in local and regional development. Regional Studies. doi:10.1080/00343404.2016.1158802

Rodríguez-Pose, A., \& Garcilazo, E. (2015). Quality of government and the returns of investment: Examining the impact of cohesion expenditure in European regions. Regional Studies, 49, 1274-1290. doi:10.1080/00343404.2015.1007933

Roy, A. (2011). Slumdog cities: Rethinking subaltern urbanism. International Journal of Urban and Regional Research, 35(2), 223-238. doi:10.1111/j.1468-2427.2011.01051.x

Scott, A. J., \& Storper, M. (2015). The nature of cities: The scope and limits of urban theory. International Journal of Urban and Regional Research, 39(1), 1-15. doi:10.1111/14682427.12134

Szerb, L., Acs, Z. J., Autio, E., Ortega-Argilés, R., \& Komlósi, E. (2013). REDI: The regional entrepreneurship and development index - measuring regional entrepreneurship, final report. Brussels: European Commission, Directorate-General for Regional and Urban policy. doi:10.2776/79241

Turok, I. (2016). Getting urbanisation to work in Africa: The role of the urban landinfrastructure-finance nexus. Area Development and Policy, 1(1), 30-47. doi:10.1080/23792949.2016.1166444

Westlund,H.,Larsson, J. P.,\&Olsson, A.R. (2014). Start-ups and local entrepreneurial social capital in the municipalities of Sweden. Regional Studies, 48, 974-994.

doi:10.1080/00343404.2013.865836 